\title{
Biochemical characterization of an enantioselective esterase from Brevundimonas sp. LY-2
}

Jing Zhang ${ }^{1,2}$, Mengjun Zhao ${ }^{1}$, Die Yu' ${ }^{1}$, Jingang Yin ${ }^{3}$, Hao Zhang ${ }^{1}$ and Xing Huang ${ }^{1 *}$

\begin{abstract}
Background: Lactofen, a member of the diphenylether herbicides, has high activity and is commonly used to control broadleaf weeds. As a post-emergent herbicide, it is directly released to the environment, and easily caused the pollution. This herbicide is degraded in soil mainly by microbial activity, but the functional enzyme involved in the biodegradation of lactofen is still not clear now.

Results: A novel esterase gene lacH, involved in the degradation of lactofen, was cloned from the strain Brevundimonas sp. LY-2. The gene contained an open reading frame of $921 \mathrm{bp}$, and a putative signal peptide at the N-terminal was identified with the most likely cleavage site between Ala 28 and Ala 29. The encoded protein, LacH, could catalyze the hydrolysis of lactofen to form acifluorfen. Phylogenetic analysis showed that LacH belong to family $\mathrm{V}$ of bacterial lipolytic enzymes. Biochemical characterization analysis showed that $\mathrm{LaCH}$ was a neutral esterase with an optimal $\mathrm{pH}$ of 7.0 and an optimal temperature of $40^{\circ} \mathrm{C}$ toward lactofen. Besides, the activity of LacH was strongly inhibited by $\mathrm{Hg}^{2+}$ and $\mathrm{Zn}^{2+}$. LacH preferred short chain $p$-nitrophenyl esters $\left(\mathrm{C}_{2}-\mathrm{C}_{6}\right)$, exhibited maximum activity toward $p$-nitrophenyl acetate. Furthermore, the enantioselectivity of $\mathrm{LacH}$ during lactofen hydrolysis was also studied, and the results show that $R-(-)$-lactofen was degraded faster than $S$-(+)-lactofen, indicating the occurrence of enantioselectivity in the enzymatic reaction.
\end{abstract}

Conclusions: Our studies characterized a novel esterase involved in the biodegradation of diphenylether herbicide lactofen. The esterase showed enantioselectivity during lactofen degradation, which revealed the occurrence of enzyme-mediated enantioselective degradation of chiral herbicides.

Keywords: Esterase, Lactofen, Brevundimonas sp., Enantioselective degradation

\section{Background}

Many pesticides in current use contain chiral structures, which consist of enantiomers [1]. Enantiomers of a chiral compound exhibit identical physical and chemical properties [2]. However, their toxicities, biological activities and environmental fates vary because biological processes usually show high enantioselectivity [3, 4]. Enantioselective analysis is required for a full understanding of the biological behavior of chiral compounds.

\footnotetext{
${ }^{*}$ Correspondence: huangxing@njau.edu.cn

${ }^{1}$ Key Laboratory of Agricultural Environmental Microbiology, Ministry of Agriculture, College of Life Sciences, Nanjing Agricultural University, Nanjing 210095, China

Full list of author information is available at the end of the article
}

Information on the enantioselective degradation dynamics of chiral pesticides will help us to evaluate the impacts of such pesticides to environment. Enantioselective degradation in soils has been observed for various chiral pesticides, such as mecoprop, dichlorprop, metalaxyl and malathion [5-7]. When one enantiomer is preferentially degraded, the enantiomeric ratio [ER, the ratio of the concentration of $(+)$-enantiomers to $(-)$-enantiomers] deviates from the original value $[2,8]$. The occurrence of such selective degradation involves the mediation of bacteria, enzymes, or other biological entities.

Diphenyl ether herbicides are widely used to control broadleaf weeds in cereal crops, soybeans, peanuts, and potatoes [9]. This class of herbicides has been proved 
to inhibit protoporphyrinogen oxidase, thereby resulting in the accumulation of protoporphyrin and blockage of chlorophyll formation $[10,11]$. Their frequent occurrence in natural waters and soils indicate that they may be important environmental contaminants [12-14]. Lactofen is an important member of the diphenyl ether family. It has one chiral center in the alkyl moiety and consists of two enantiomers. This herbicide is applied as a racemic mixture, although its herbicidal activity is almost entirely attributed to the $S$-enantiomer [15]. The enantioselective degradation of lactofen in soil and sediment has been studied by Diao et al. $[15,16]$. The $S$-enantiomer was preferentially degraded either in soil or sediment, resulting in a relative enrichment of the $R$-enantiomer. However, to our knowledge, no studies have focused on the enantioselectivity of the degrading-enzyme involved in lactofen metabolism so far.

The lactofen-degrading strain Brevundimonas sp. LY-2 was isolated from enrichment cultures inoculated with lactofen-contaminated soil sample in our lab. This strain could degrade about $80 \%$ of $50 \mathrm{mg} \mathrm{L}^{-1}$ lactofen in 5 days of incubation in flasks. The metabolic behaviors of the herbicide in the media were described [17]. In this study, we have found that the degradation process of lactofen by LY-2 is enantioselective, with $R-(-)$-lactofen being degraded faster than the $S$-(+)-enantiomer, which implies that the enzyme involved in lactofen degradation probably has the enantioselectivity between the different enantiomers. In this study, a novel esterase gene $l a c H$ involved in lactofen degradation was cloned from this strain, and the biochemical properties of the purified enzyme LacH were determined. The enantioselectivity of $\mathrm{LacH}$ during lactofen hydrolysis was also investigated.

\section{Results}

\section{Cloning and sequence analysis of the esterase gene}

The total DNA was extracted from strain Brevundimonas sp. LY-2, and the genomic library was constructed. A positive clone that produced a transparent halo around the colony was screened from approximately 3000 transformants. The sequencing results show that the inserted fragment in the transformant was $3453 \mathrm{bp}$ containing three complete ORFs. These ORFs were each subcloned into the pMD18-T vector and then transformed into competent Escherichia coli DH5 $\alpha$ cells. One ORF, designated as $l a c H$, was confirmed to be the target gene encoding the lactofen-hydrolyzing enzyme. This ORF consists of $921 \mathrm{bp}$ that encode a protein with 306 amino acids. A putative signal peptide at the $\mathrm{N}$-terminal was identified by the SignalP 4.1 server, with the most likely cleavage site situated between amino acids Ala 28 and Ala 29. Thus, the encoded protein, $\mathrm{LacH}$, is a secretory protein. The BLAST results showed that $\mathrm{LacH}$ shared moderate identities with some characterized $\alpha / \beta$-hydrolase fold proteins, and showed the highest identity (71\%) with esterase sys410 (AFE88176), a thermostable pyrethroid-hydrolyzing enzyme isolated from uncultured bacterium through the metagenomic approach [18]. Among the other characterized proteins, LacH shared $48 \%$ identity with an $\alpha / \beta$ hydrolase fold protein from Caulobacter crescentus CB15 (AAK24201) [19], 40\% identity with a triacylglycerol lipase from Moraxella sp. TA144 (CAA37863) [20], and only $27 \%$ identity with a triacylglycerol lipase from Psychrobacter immobilis B10 (CAA47949) [21].

Multiple sequence alignment of $\mathrm{LacH}$ and other esterase/lipase proteins demonstrates that $\mathrm{LaCH}$ contained a typical Ser-His-Asp/Glu (Ser128, Asp233 and His286) catalytic triad and also contained the conserved GXSXG motif (residues 126-130) (Fig. 1) [22, 23]. Bacterial esterases/lipases have been classified into eight different families based on their amino acid sequences and biochemical properties [24]. A phylogenetic tree was constructed to verify the evolutionary relationships between $\mathrm{LacH}$ and other known esterases/lipases. The phylogenetic tree showed that the LacH protein belonged to family $\mathrm{V}$ of lipolytic enzymes (Fig. 2).

\section{Expression and purification of the recombinant $\mathrm{LaCH}$}

The $\mathrm{lacH}$ gene, minus the signal peptide, was cloned into the expression vector pET-29a (+) to generate pET-LacH and expressed in E. coli BL21 (DE3) with a C-terminal His-tag. Recombinant $\mathrm{LacH}$ was purified from the crude extract using Ni-nitrilotriacetic acid affinity chromatography. The molecular mass of the denatured enzyme was approximately $30 \mathrm{kDa}$, as showed by SDS-PAGE (Fig. 3), which matched the predicted molecular mass $(29,451 \mathrm{Da})$. Gel filtration indicated a molecular mass of $62 \mathrm{kDa}$. Comparison of this value with the calculated molecular mass suggested that this enzyme was a dimer.

\section{Characteristics of LacH}

The effect of temperature on enzyme activity was examined in the range of $15-70^{\circ} \mathrm{C}$ (Fig. 4). The maximum $\mathrm{LacH}$ activity was observed at $40{ }^{\circ} \mathrm{C}$, and the minimal enzyme activity was observed at temperatures above $60{ }^{\circ} \mathrm{C}$. Thermostability was determined by analyzing the residual enzyme activity after pre-incubation at temperatures ranging from 15 to $80^{\circ} \mathrm{C}$ for $30 \mathrm{~min}$ (Fig. 4). The enzyme was fairly stable up to $60{ }^{\circ} \mathrm{C}$, and retained approximately $88 \%$ of its activity at $60^{\circ} \mathrm{C}$ for $30 \mathrm{~min}$. Moreover, $\mathrm{LacH}$ retained only $12 \%$ of its activity at $70{ }^{\circ} \mathrm{C}$, and was completely inactivated at $80{ }^{\circ} \mathrm{C}$. These results showed that $\mathrm{LacH}$ was a potential thermostable esterase. The optimal $\mathrm{pH}$ of $\mathrm{LacH}$ was determined at $40{ }^{\circ} \mathrm{C}$ from $\mathrm{pH} 4.0$ to $\mathrm{pH} 10.0$ (Fig. 5). $\mathrm{LacH}$ showed the highest activity at neutral $\mathrm{pH}$, with more than $80 \%$ of its maximal activity from $\mathrm{pH} 6.5$ to $\mathrm{pH} 7.0$. 
$\mathrm{LacH}$

AFE88176

AAK24201

CAA4 7949

CAA 37863

$\mathrm{LacH}$

AFE88176

AAK24201

CAA 47949

CAA37863

$\mathrm{IacH}$

AEE 88176

AAK24201

CAA 47949

CAA 37863

$\mathrm{LacH}$

AFE88176

AAK24201

CAA 47949

CAA 37863

$\mathrm{IaCH}$

AEE88176

AAK24201

CAA 47949

CAA 37863

$\mathrm{LacH}$

AEE88176

AAK24 201

CAA47949

CAA37863

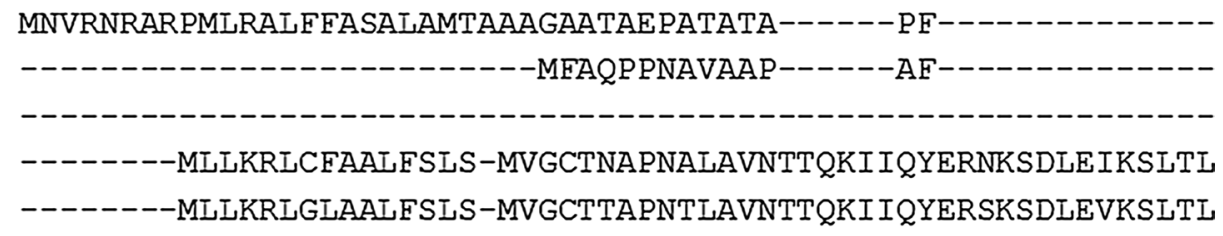

-VSDRLSV--EVVGQGSDVIII PGLASSREVWRTTADRLKANHRVHLVQLSGEAGQAWT-ASDRLSV--EVVGTGPDVIII PGEASSREVWRAEAERLKATHRVHLVQLAGFAGEPWT----MTV--TVVGQGPDVIII PGLASSSAVWDATVKQISATHRVHVVQVAGEAGAPVAG ASGDKMVYAENGNVAGEPIIIIHGEGGNKDNETRIARQLEGYHLI-IPDLIGEGESSKPM ASGDKMVYAENDNVTGEPLLIIHGFGGNKDNFTRIADKLEGYHLI-IPDLLGFGNSSKPM

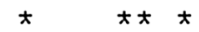

HGDGAFVQPEVDELARYIRQSGLVRP-AVI THSMG SLSGLMLAQQHPELVGRLMTVDSLP HGDGLFVAPMIEELARYIRETELDKP-AVIIGHSMGGLSGILIAQAHPDLVGKVMSVDSLP NADGAVVGPLVEAVDGYIKAKGLKSP-AVIGHSIGGFTGLLIAQRHPGSIGRLMIVDSLP SADY-RSEAQRTRLHELIQAKGLASNIHVGGNSMGGAISVAYAAKYPKDVKSLWLVDSAG TADY-RADAQATRLHEIMQAKGLASNTHVGGNSMGGAISVAYAAKYPKEIKSLWLVDTAG

๘

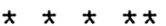

t $\quad$

t

FYSALFGPTATAETARPEADQAAAQIIGADATAYRAQQTAAAQGISRDPAEQARIVDWSM FFSALFGPQVTAEMALPFADQAAQSMLNPDADAFRAGQAQSAVGLARDPATRTAMVDWSM FFSLLFSPAATPEMVRPQAVQMRDATVAMSPEAFAGQQAMGAPRFVKSAEGQKQVIAWGG EWSAGIPKSIEGATLE--------------------NNPLI IKSNEDFYKMYDEVM FWSAGVPKSIEGATLE--------------------NNPIIINSKEDFYKMYDEVM $\star \star$

ASD--------------RHAVAAAIRDVMTTDARPG----ITAMTTPVTALYAADVD ASD-------------RQALASAIREVMTTDARPA----IATMTTPVWAIYASDAD ASS--------------PSVVGRAMYDILVTDARGD----IAKVKAPTTLIYAYDTA YKPPYIPKSVKAVFAQERIKNKEIDAKILEQIVTDNVEERAKIIAQYKIPTLVVWGDKDQ YKPPYIPKSVKAVFAQERINNKAIDTKILEQIVTDNVEERAKI IAKYNIPTLVVWGDKDQ GGAPAAVADAMWTREYSTIPGATITRVDGSRHFIMADQPRRFAEAVDRFLAD----GGAPAAMADALWTREYATIPGVHLERVDDSRHFIMADQPQREAAVVDRFLAE----MGMPSTAADRLFVDAYAGLPGLKATRIDDARHFIMLDQPQAFAQAVADFLK-----I IKPETVN-----IIKKII PQAQVIMMEDVGHVPMVEALDETADNYKAFRS ILEAQR VIKPETTE-----IIKEIIPQAQVIMMNDVGHVPMVEAVKDTANDYKAFRDGLKK--

Fig. 1 Multiple alignment of $\mathrm{LaCH}$ with other related proteins. Except for $\mathrm{LaCH}$ (this study), all other protein sequences were retrieved from GenBank (NCBI). AFE88176, esterase sys410 from uncultured bacterium; AAK24201, a/ $\beta$-hydrolase fold family from Caulobacter crescentus CB15; CAA47949, triacylglycerol lipase from Psychrobacter immobilis B10; CAA37863, triacylglycerol lipase from Moraxella sp. TA144. The conserved pentapeptide of GXSXG is boxed. Triangles indicate the putative catalytic triad of serine, aspartate, and histidine residues. Identical amino acid residues are marked by asterisk

The effects of metal ions on enzyme activity were determined using various metal ions at $1 \mathrm{mM}$ (Fig. 6). Activity of $\mathrm{LacH}$ was strongly inhibited by more than $70 \%$ with the presence of $\mathrm{Hg}^{2+}$ and $\mathrm{Zn}^{2+}$, whereas the presence of $\mathrm{Ni}^{2+}$ caused approximately 35\% inhibition. Moreover, the addition of $\mathrm{Mn}^{2+}, \mathrm{Mg}^{2+}, \mathrm{Ca}^{2+}$, and $\mathrm{Cu}^{2+}$ showed only slight effects on the enzyme activity (10-20\% inhibition).

\section{Substrate specificity and activity of LacH}

The substrate specificity of $\mathrm{LacH}$ was determined using $p$-nitrophenyl esters with various acyl chain lengths $\left(\mathrm{C}_{2}\right.$, $\mathrm{C}_{4}, \mathrm{C}_{6}, \mathrm{C}_{8}$, and $\mathrm{C}_{12}$ ) as substrates (Table 1 ). LacH showed the highest activity with $p$-nitrophenyl acetate $\left(\mathrm{C}_{2}\right)$ $\left(118 \mu \mathrm{mol} \mathrm{min}{ }^{-1} \mathrm{mg}^{-1}\right)$ and the activity decreased when the aliphatic chain length of the substrate increased. The 


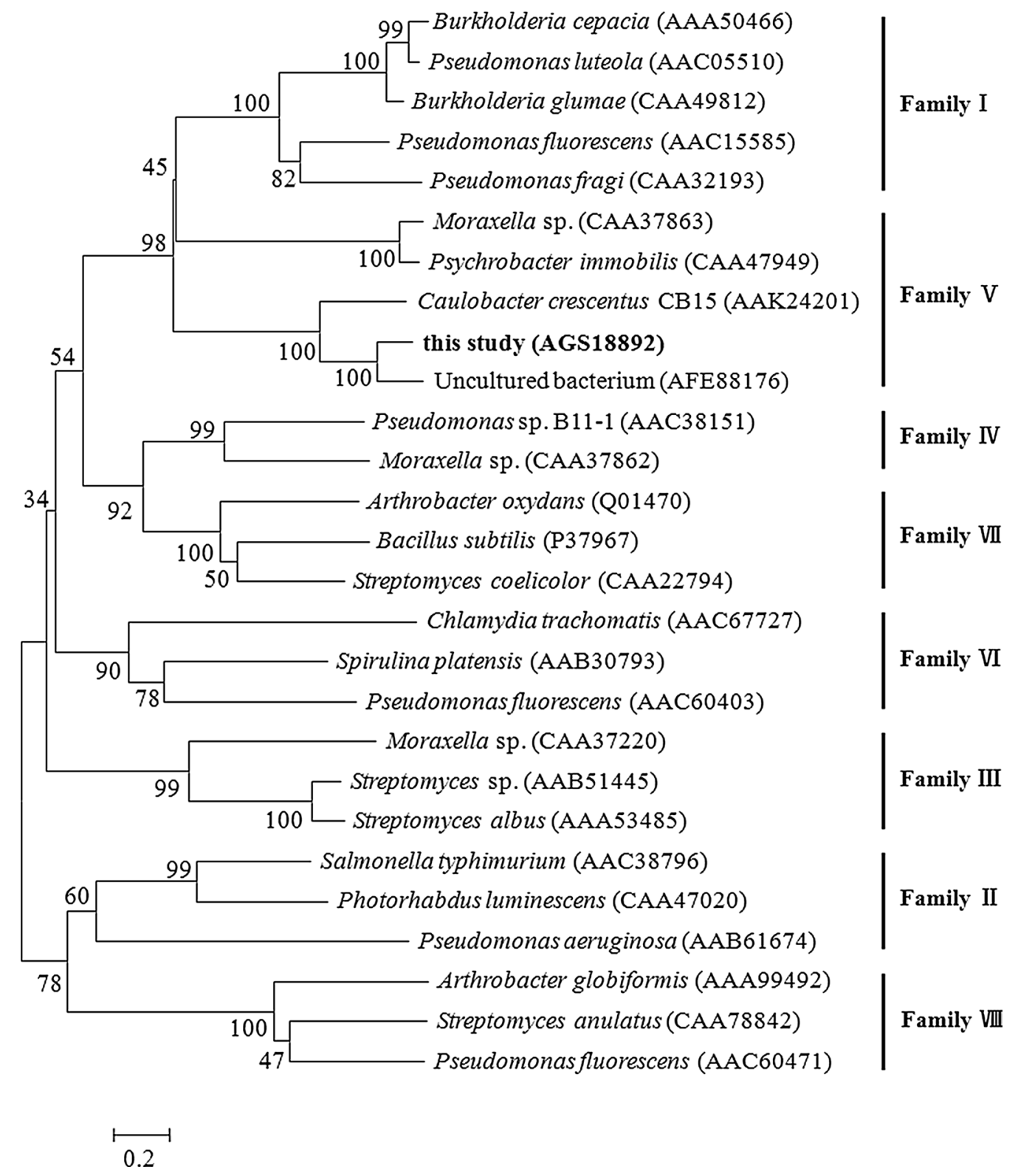

Fig. 2 Phylogenetic analysis of $\mathrm{LaCH}$ and related esterase/lipase proteins. Phylogenetic relationship of $\mathrm{LaCH}$ and esterase/lipase proteins of eight different families was performed using the program MEGA 6.0. Except for LacH, all other protein sequences were retrieved from GenBank (NCBI).

The scale at the bottom represents the number of substitution events

activity toward $p$-nitrophenyl caprylate $\left(\mathrm{C}_{8}\right)$ in the assay was observed to be very low, and no significant esterase activity was observed for the $p$-nitrophenyl laurate $\left(\mathrm{C}_{12}\right)$ under the same assay conditions. For $\mathrm{C}_{2}$, the $k_{\text {cat }}$ and $K_{\mathrm{m}}$ values were $8.39 \mathrm{~s}^{-1}$ and $0.147 \mathrm{mM}$, respectively. With the increase in aliphatic chain length from 4 to $12\left(\mathrm{C}_{4}{ }^{-}\right.$ $\left.\mathrm{C}_{12}\right), k_{\text {cat }}$ decreased, whereas $K_{\mathrm{m}}$ increased.

Degradation efficiency by $\mathrm{LacH}$ with lactofen as the substrate was tested by high-performance liquid chromatography (HPLC) analysis (Additional file 1: Figure
S1). The hydrolysis rate of lactofen was $59.3 \%$ under assay conditions of $\mathrm{pH} 7.0$ and $40{ }^{\circ} \mathrm{C}$ for $15 \mathrm{~min}$ (Additional file 1: Table S1). The metabolite of lactofen hydrolysis by $\mathrm{LacH}$ was confirmed to be acifluorfen (Additional file 1: Figure S1).

\section{Enantioselectivity of LacH}

The enantioselectivity of $\mathrm{LacH}$ in the enzymatic reaction was investigated by evaluating the changes in enantiomer composition for lactofen. Enantiomers of 

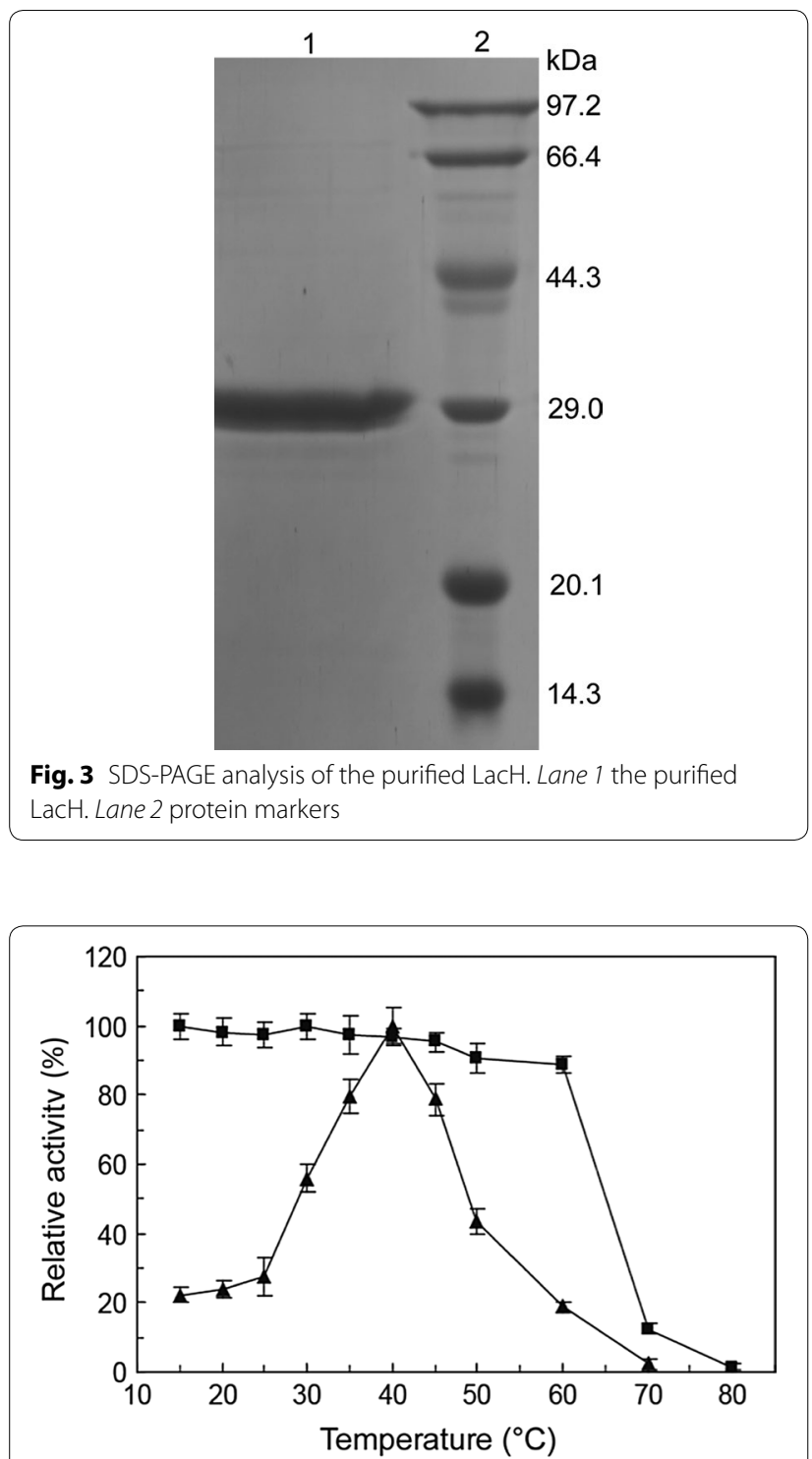

Fig. 4 Effect of temperature on the activity (triangles) and stability (boxes) of LacH. The activity of the enzyme at different temperatures was measured in $50 \mathrm{mM}$ sodium phosphate buffer ( $\mathrm{pH}$ 7.0) using lactofen as the substrate. For determination of the thermostability, the enzyme was preincubated at various temperatures ranging from 15 to $80^{\circ} \mathrm{C}$ for $30 \mathrm{~min}$, and the residual activity was determined at $\mathrm{pH}$ 7.0 and $40^{\circ} \mathrm{C}$

lactofen were completely separated by HPLC with a chiral column (Additional file 1: Figure S2). ER [ER $=S-(+)$ lactofen/R-(-)-lactofen] was adopted as the standard descriptor [2]. At the initial point of the reaction, no substrate was hydrolyzed, and the initial ER was 0.85 . When the enzymatic reaction proceeded, the ER values gradually increased from 0.85 to 1.37 (Fig. 7). This steady increase in ER in the enzymatic reaction suggested that the $R-(-)$-lactofen was preferentially degraded compared with the $S$-(+)-lactofen. The stereospecific enzymatic

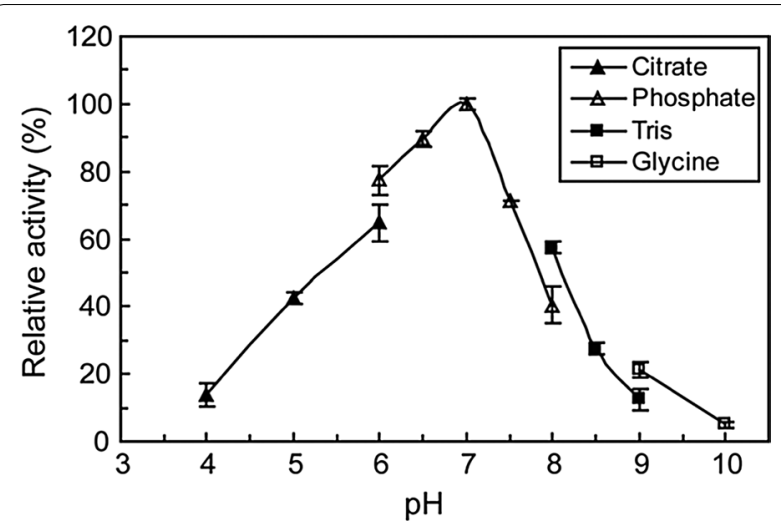

Fig. 5 The effect of $\mathrm{pH}$ on the activity of $\mathrm{LaCH}$. The activity of the enzyme at different $\mathrm{pH}$ was measured at $40^{\circ} \mathrm{C}$

reaction implies that $\mathrm{LacH}$ involved in the conversion of lactofen could differentiate the $S$-(+)-lactofen from the $R$-(-)-lactofen.

\section{Discussion}

Esterases (EC 3.1.1.1) and lipases (EC 3.1.1.3) are widely distributed in animals, plants and microorganisms. They have played an important role in the hydrolysis of a wide range of xenobiotics containing ester bonds. Esterases and lipases found in bacteria have been divided into eight different families based on their amino acid sequences and biochemical properties [24]. The esterase LacH that was cloned from strain LY-2 was responsible for converting lactofen to acifluorfen. Cheng et al. [25] studied the acute toxicity of lactofen and its metabolite acifluorfen in the aquatic algae Scenedesmus obliquus, and the results indicated that the toxicity of the acifluorfen was lower than that of the lactofen. Wang et al. [26] evaluated the toxic effects of the herbicide lactofen and acifluorfen to the aquatic plant Lemna minor, and they found L. minor growth was inhibited in the order of lactofen $>$ acifluorfen. Both of these studies have found that acifluorfen had a lower toxicity to aquatic organisms than lactofen. To the best of our knowledge, LacH is the first identified esterase for lactofen hydrolysis in microorganisms. LacH belonged to the $\alpha / \beta$-hydrolase fold protein family and contained both the typical Ser-His-Asp/Glu (Ser128, Asp233 and His286) catalytic triad and the conserved pentapeptide sequence GXSXG (residues 126-130) of $\alpha / \beta$-hydrolase fold proteins [22, 23]. Amino acid sequence alignment and phylogenetic analysis suggested that LacH belonged to family $\mathrm{V}$ of lipolytic enzymes.

The substrate spectrum of $\mathrm{LacH}$ was found to be broad. It was able to hydrolyze various $p$-nitrophenyl esters of short-medium chain fatty acids $\left(\mathrm{C}_{2}-\mathrm{C}_{8}\right)$. The catalytic efficiency value $\left(k_{\text {cat }} / K_{\mathrm{m}}\right)$ demonstrated that $p$-nitrophenyl acetate $\left(C_{2}\right)$ was the most efficient catalytic substrate. 


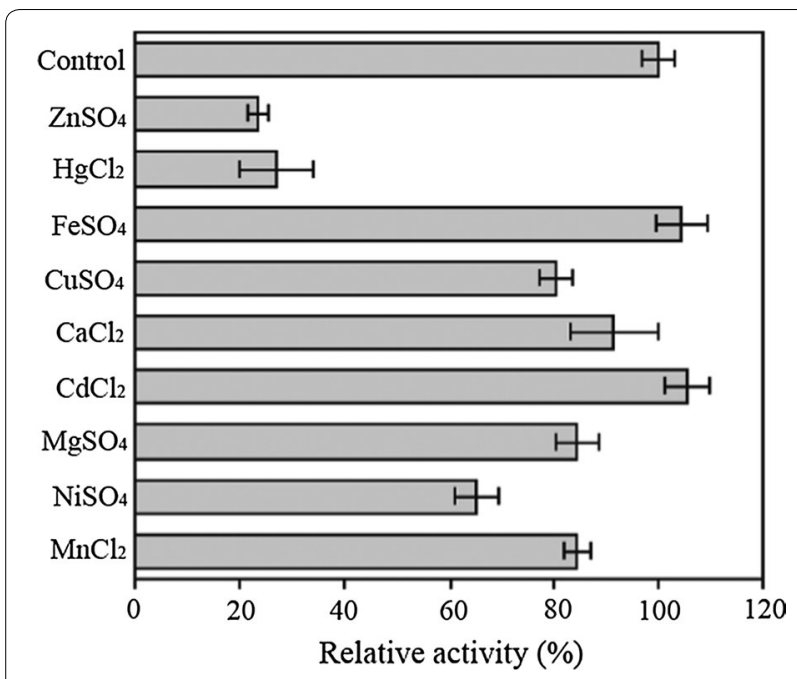

Fig. 6 The effects of metal ions on the activity of LacH. Control reaction was carried out in the absence of metal ion

The specificity profile indicated that LacH should be classified as an esterase because maximal activity was observed on the short-chain fatty acid esters, while the activity of long-chain fatty acid esters was low. LacH could also hydrolyze other pesticides with similar carboxyl ester, such as fenoxaprop-P-ethyl, cyhalofop-butyl, fluazifop- $P$-butyl, quizalofop- $P$-ethyl and fluoroglycofen (Additional file 1: Table S1).

The degradation process of lactofen by Brevundimonas sp. LY-2 is enantioselective, with $R$-(-)-lactofen being degraded faster than the $S$-(+)-enantiomer (Additional file 1: Table S2), which implies that the enzyme involved in lactofen conversion can differentiate between the enantiomers. Previous studies have shown that the herbicidally active $S$-(+)-lactofen was preferentially degraded either in soil or sediment, resulting in relative enrichment of the $R$-(-)-form $[15,16]$. However, studies on enantioselectivity of biotransformation enzyme involved in lactofen metabolism by microorganisms are limited. In this study, we demonstrated the occurrence of enantioselectivity in biotransformation of lactofen by $\mathrm{LacH}$ and the rising of ER indicated the $R-(-)$-lactofen was preferentially degraded over the $S$-(+)-form.

\section{Conclusion}

Up to now, little is known about the functional enzyme involved in the degradation of lactofen by pure culture. In this paper, a novel esterase LacH was functionally expressed and characterized from Brevundimonas sp. LY-2. This is the first report of a functional enzyme involved in the degradation of diphenylether herbicide. In this paper, the enantioselectivity of $\mathrm{LacH}$ during lactofen hydrolysis was studied, and the results show that $R-(-)$-lactofen was degraded faster than $S$-(+)-lactofen, indicating the occurrence of enantioselectivity in the enzymatic reaction, which may help in understanding the mechanism of enantioselective degradation of chiral pesticides. In the future, for a better understanding of enantioselective degradation, detailed studies on recognition mechanism of enzymes to differentiate between enantiomers will be needed.

\section{Methods}

Chemicals

Lactofen (99\% purity) was purchased from Sigma-Aldrich Chemical Co. (Shanghai, China). All the $p$-nitrophenyl

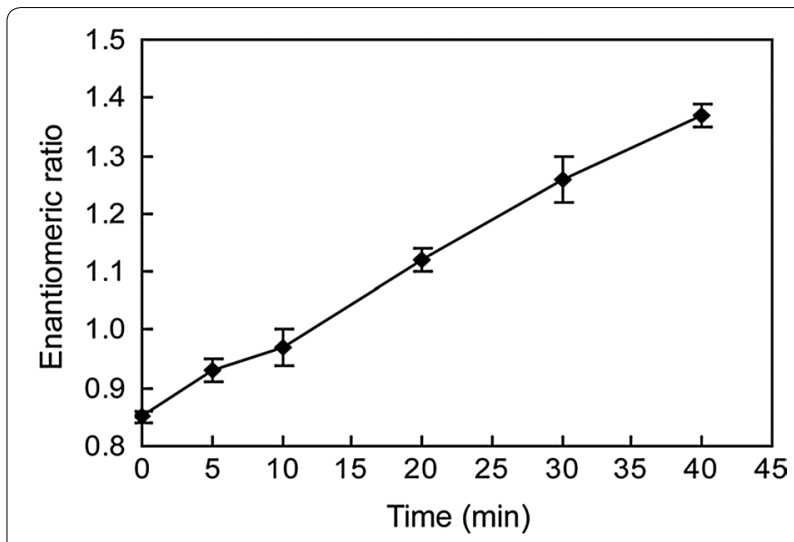

Fig. 7 ER changes in the enzymatic reaction with lactofen as the substrate. The enantiomeric ratio $[E R=S-(+)$-lactofen/R-(-)-lactofen]

Table 1 Substrate specificity and kinetic constants of LacH

\begin{tabular}{lllll}
\hline Substrate & $\begin{array}{l}\text { Specific activity } \\
\left(\boldsymbol{\mu} \mathbf{m o l ~} \mathbf{~ m i n}^{-\mathbf{1}} \mathbf{~ m g}^{-\mathbf{1}}\right)\end{array}$ & $\boldsymbol{k}_{\mathbf{c a t}}\left(\mathbf{s}^{-\mathbf{1}}\right)$ & $\boldsymbol{K}_{\mathbf{m}}(\mathbf{m M})$ & $\boldsymbol{k}_{\text {cat }} / \boldsymbol{K}_{\mathbf{m}}\left(\mathbf{s}^{-\mathbf{1}} \mathbf{m M} \mathbf{M}^{-\mathbf{1}}\right)$ \\
\hline Lactofen & $2.97 \pm 0.61$ & $0.87 \pm 0.09$ & $0.067 \pm 0.002$ & 12.9 \\
$p$-Nitrophenyl acetate & $118 \pm 5.3$ & $8.39 \pm 0.28$ & $0.147 \pm 0.008$ & 50.1 \\
$p$-Nitrophenyl butyrate & $88.1 \pm 3.2$ & $7.48 \pm 0.45$ & $0.185 \pm 0.009$ & 40.4 \\
$p$-Nitrophenyl caproate & $15.8 \pm 1.2$ & $3.47 \pm 0.13$ & $0.208 \pm 0.012$ & 16.7 \\
$p$-Nitrophenyl caprylate & $4.90 \pm 0.18$ & $0.767 \pm 0.06$ & $0.335 \pm 0.016$ & 2.29 \\
$p$-Nitrophenyl laurate & $\mathrm{ND}$ & $\mathrm{ND}$ & $\mathrm{ND}$ & $\mathrm{ND}$ \\
\hline
\end{tabular}

ND not detectable 
esters were purchased from Sigma. Methanol, $n$-hexane, and isopropanol were of pure chromatographic grade. All other chemicals used were of analytical grade.

\section{Bacterial strains and plasmids}

Brevundimonas sp. LY-2 was deposited in our laboratory. E. coli $\mathrm{DH} 5 \alpha$ and E. coli BL21 (DE3) were used as the host for gene cloning and protein expression, respectively. The pUC118 and pET-29a (+) were used to construct the genomic library and express the target protein, respectively.

\section{Screening of genomic library}

DNA manipulation was performed as described by Sambrook and Russell [27]. To construct the genomic library, genomic DNA of Brevundimonas sp. LY-2 was subjected to partial digestion with Sau3AI. Fractions containing approximately 2-4 kb DNA fragments were pooled, ligated into the BamHI site of the plasmid pUC118, and transformed into E. coli DH5 $\alpha$. The library was plated onto LB agar containing $100 \mathrm{mg} \mathrm{L}^{-1}$ ampicillin and $100 \mathrm{mg} \mathrm{L}^{-1}$ lactofen, and incubated at $37^{\circ} \mathrm{C}$ for approximately $24 \mathrm{~h}$. The transformants harboring the plasmid containing the functional gene and producing transparent halos were screened and further tested by HPLC analysis to determine their lactofen-degrading ability. Positive recombinant plasmids were extracted and submitted for sequencing.

\section{Sequence analysis}

Nucleotide and deduced amino acid sequence analyses were performed using Omiga Software 2.0. BlastN and BlastP were used for the nucleotide sequence and deduced amino acid identity searches (http://www.ncbi. nlm.nih.gov/Blast), respectively. The signal peptide of the amino acid sequence was predicted using SignalP 4.1 (http://www.cbs.dtu.dk/services/SignalP/). Multiple sequence alignment was performed with Clustal W program [28]. Phylogenetic analysis was carried out via the neighbor-joining method using MEGA 6.0. Bootstrapping of 1000 replicates was performed to estimate the confidence levels of phylogenetic reconstructions [29].

\section{Gene expression and purification of the recombinant $\mathrm{LacH}$}

The open reading frame (ORF) of lacH without the signal peptide was amplified by PCR using primers $\mathrm{F} 1$ (5'-GGAATTCCATATGGCGACCGCCGAACCGG-3'; NdeI site was underlined) and R1 (5'-CCGCTCGAGGTCCGCCAGGAACCGGTC-3'; XhoI site was underlined). The PCR product, digested by NdeI and XhoI, was inserted into pET-29a (+) and the recombinant plasmid was then transformed into $E$. coli BL21 (DE3). The fusion protein was obtained when cells in mid-log phase (optical density at $600 \mathrm{~nm}=0.6$ ) were induced with $1.0 \mathrm{mM}$ isopropyl- $\beta$-D-thiogalactopyranoside at $30^{\circ} \mathrm{C}$ for $3 \mathrm{~h}$. The harvested cells were washed and disrupted by sonication. Cell debris was removed by centrifugation. The supernatant was loaded onto a His-Bind resin (Novagen). The target protein was eluted with $100 \mathrm{mM}$ imidazole after elution of non-target proteins with 25 and $50 \mathrm{mM}$ imidazole. The enzyme was dialysis against $50 \mathrm{mM}$ sodium phosphate buffer ( $\mathrm{pH}$ 7.0) for $24 \mathrm{~h}$, and concentrated using an Amicon ultrafiltration tube. The protein concentration was quantified by the Bradford method using bovine serum albumin (BSA) as the standard. The purified protein was analyzed by $12 \%$ SDS-PAGE gel electrophoresis. The molecular mass markers used were rabbit muscle phosphorylase $b(97.2 \mathrm{kDa})$, BSA $(66.4 \mathrm{kDa})$, hen egg white ovalbumin $(44.3 \mathrm{kDa})$, bovine carbonic anhydrase $(29.0 \mathrm{kDa})$, soybean trypsin inhibitor $(20.1 \mathrm{kDa})$, and hen egg white lysozyme $(14.3 \mathrm{kDa})$. The molecular mass of the native protein was determined by gel filtration on a Superdex 200 column. The molecular mass markers used were thyroglobulin $(669 \mathrm{kDa})$, ferritin $(440 \mathrm{kDa})$, bovine gamma globulin $(158 \mathrm{kDa})$, chicken ovalbumin $(44 \mathrm{kDa})$, carbonic anhydrase $(29 \mathrm{kDa})$, and ribonuclease $\mathrm{A}(13.7 \mathrm{kDa})$.

\section{Biochemical characterization}

The optimal temperature for lactofen degradation by pure enzyme was determined in $50 \mathrm{mM}$ sodium phosphate buffer ( $\mathrm{pH} 7.0)$ at different temperatures from 15 to $70{ }^{\circ} \mathrm{C}$. To determine thermostability, the enzyme was pre-incubated at various temperatures ranging from 15 to $80{ }^{\circ} \mathrm{C}$ for $30 \mathrm{~min}$, and the residual activity was determined. The optimal $\mathrm{pH}$ was measured at $40{ }^{\circ} \mathrm{C}$ with $\mathrm{pH}$ ranging from 4.0 to 10.0. The buffers used were $50 \mathrm{mM}$ citric acid-sodium citrate $(\mathrm{pH} 4.0-\mathrm{pH}$ 6.0), sodium phosphate (pH 6.0- $\mathrm{pH} 8.0)$, Tris- $\mathrm{HCl}(\mathrm{pH} 8.0-\mathrm{pH} 9.0)$, and glycine- $\mathrm{NaOH}(\mathrm{pH} 9.0-\mathrm{pH}$ 10.0). To investigate the effects of metal ions on enzyme activity, the enzyme was pre-incubated with various metal salts at $40{ }^{\circ} \mathrm{C}$ for 30 min. Metal salts $\left(\mathrm{FeSO}_{4}, \mathrm{CdCl}_{2}, \mathrm{CaCl}_{2}, \mathrm{MnCl}_{2}, \mathrm{MgSO}_{4}\right.$, $\mathrm{CuSO}_{4}, \mathrm{ZnSO}_{4}, \mathrm{HgCl}_{2}$ and $\mathrm{NiSO}_{4}$ ) were added at a final concentration of $1 \mathrm{mM}$. The residual activity was assayed and expressed as a percentage of the activity obtained in the absence of added metal ions.

\section{Substrate specificity and kinetics study}

Substrate specificity of $\mathrm{LacH}$ was determined using lactofen, $p$-nitrophenyl acetate $\left(C_{2}\right), \quad p$-nitrophenyl butyrate $\left(\mathrm{C}_{4}\right), p$-nitrophenyl caproate $\left(\mathrm{C}_{6}\right), p$-nitrophenyl caprylate $\left(\mathrm{C}_{8}\right)$, and $p$-nitrophenyl laurate $\left(\mathrm{C}_{12}\right)$ as substrates. Hydrolytic activity toward $p$-nitrophenyl esters was assayed in accordance with the method described by Gao et al. [30]. Hydrolytic activity toward lactofen was 
performed as described below. For kinetic studies, stock solutions of each substrate were appropriately diluted into five different concentrations around the $K_{\mathrm{m}}$ values. Kinetic values were obtained from Lineweaver-Burk plots against various substrate concentrations.

\section{HPLC-MS/MS analysis of lactofen degradation by LacH} Hydrolysis of lactofen was assayed in $50 \mathrm{mM}$ sodium phosphate buffer $(\mathrm{pH} 7.0)$ at $40{ }^{\circ} \mathrm{C}$ with a final concentration of $50 \mathrm{mg} \mathrm{L}^{-1}$ lactofen. Briefly, $1.5 \mu \mathrm{L}$ of lactofen stock solution $\left(100,000 \mathrm{mg} \mathrm{L}^{-1}\right.$, dissolved in methanol) was added to $3 \mathrm{~mL}$ sodium phosphate buffer $(50 \mathrm{mM}, \mathrm{pH}$ 7.0). The reaction was initiated by the addition of $50 \mu \mathrm{L}$ of the purified $\mathrm{LacH}\left(57.5 \mu \mathrm{g} \mathrm{mL}^{-1}\right)$ and incubation for $15 \mathrm{~min}$. The substrate residues were measured by HPLC. Control samples containing boiled enzyme solution were treated and analyzed in the same way. The metabolite of lactofen degradation by $\mathrm{LacH}$ was further confirmed by MS/MS [17].

\section{Chemical analysis}

For lactofen determination, the solution mixture was extracted with an equal volume of dichloromethane. The organic layer was dried over anhydrous $\mathrm{Na}_{2} \mathrm{SO}_{4}$, and dichloromethane was removed using a stream of nitrogen at room temperature. The residues were redissolved in methanol. All samples were analyzed by HPLC equipped with a Zorbax C-18 ODS Spherex column $(250 \mathrm{~mm} \times 4.6 \mathrm{~mm})$. The mobile phase was pure methanol and the flow rate was $1 \mathrm{~mL} \mathrm{~min}{ }^{-1}$. The UV wavelength for detection was $230 \mathrm{~nm}$, and the injection volume was $20 \mu \mathrm{L}$.

The lactofen enantiomers were separated and quantified using HPLC with a Chiralcel OD-H column $(250 \mathrm{~mm} \times 4.6 \mathrm{~mm})$. The mobile phase was $n$-hexane-isopropanol $(97: 3, \mathrm{vol} / \mathrm{vol})$, and the flow rate was $1 \mathrm{~mL} \mathrm{~min}^{-1}$. The UV wavelength for detection was $230 \mathrm{~nm}$, and the injection volume was $20 \mu \mathrm{L}$.

\section{Nucleotide sequence accession number}

The nucleotide sequence of the $\mathrm{lacH}$ gene was deposited in the GenBank database under accession number KF286657.

\section{Strain deposition}

Brevundimonas sp. LY-2 was deposited to the China General Microbiological Culture Collection Center (CGMCC3651).

\section{Statistical analysis and reproducibility}

All experiments were performed in triplicate. The values were expressed as mean $\pm \mathrm{SD}$ in the figures.

\section{Additional file}

Additional file 1: Figure S1. HPLC-MS/MS analysis of lactofen hydrolyzed by LacH. HPLC spectrum of the hydrolysis reaction by inactive enzyme (A) and active enzyme (B), respectively. MS/MS spectrum of the metabolite with retention time of 2.615 (C). Figure S2. Chiral HPLC analysis of lactofen with UV detection. Table S1. The hydrolysis rate of pesticides contained carboxylic acid esters by LacH. All of the assays were measured at $\mathrm{pH} 7.0$ and $40^{\circ} \mathrm{C}$ for $15 \mathrm{~min}$. Table S2. ER changes during the degradation process of lactofen by Brevundimonas sp. LY-2. A, at the initial point of the degradation process, no substrate was degraded; B, C and $D$, approximately 30,50 and $95 \%$ of the substrate were hydrolyzed, respectively.

\section{Authors' contributions}

$\mathrm{XH}$ and JZ designed the experiments. JZ, MZ, DY, JY and HZ performed the experiments and analyzed the data. XH and JZ wrote the paper. All authors read and approved the final manuscript.

\section{Author details \\ ${ }^{1}$ Key Laboratory of Agricultural Environmental Microbiology, Ministry of Agriculture, College of Life Sciences, Nanjing Agricultural University, Nanjing 210095, China. ${ }^{2}$ Institute of Agricultural Resources and Environment, Jiangsu Academy of Agricultural Sciences, Nanjing 210014, China. ${ }^{3}$ Laboratory of Biocatalysis and Synthetic Biotechnology, State Key Laboratory of Bioreac- tor Engineering, East China University of Science and Technology, Shang- hai 200237, China.}

\section{Acknowledgements}

The authors would like to thank Pro Jianhe Xu at East China University of Science and Technology for his valuable advices about this paper.

\section{Competing interests}

The authors declare that they have no competing interests.

\section{Availability of data and materials}

The datasets supporting the conclusions of this article are included within the article and its additional files.

\section{Funding}

This work was funded by The National Natural Science Foundation of China (41671317), the Fundamental Research Funds for the Central Universities (KYZ201635).

\section{Publisher's Note}

Springer Nature remains neutral with regard to jurisdictional claims in published maps and institutional affiliations.

Received: 18 January 2017 Accepted: 14 June 2017

Published online: 19 June 2017

\section{References}

1. Sekhon BS. Chiral pesticides. J Pestic Sci. 2009;34:1-12.

2. Liu WP, Gan JY, Schlenk D, Jury WA. Enantioselectivity in environmental safety of current chiral insecticides. Proc Natl Acad Sci. 2005;102:701-6.

3. Garrison AW. Probing the enantioselectivity of chiral pesticides. Environ Sci Technol. 2006;40:16-23.

4. Müller TA, Kohler HP. Chirality of pollutants-effects on metabolism and fate. Appl Microbiol Biotechnol. 2004;64:300-16.

5. Romero E, Matallo MB, Pena A, Sánchez-Rasero F, Schmitt-Kopplin P, Dios G. Dissipation of racemic mecoprop and dichlorprop and their pure $R$ -enantiomers in three calcareous soils with and without peat addition. Environ Pollut. 2001;111:209-15. 
6. Buerge IJ, Poiger T, Müller MD, Buser H-R. Enantioselective degradation of metalaxyl in soils: chiral preference changes with soil pH. Environ Sci Technol. 2003;37:2668-74.

7. Sun MJ, Liu DH, Zhou GX, Li JD, Qiu XX, Zhou ZQ, Wang P. Enantioselective degradation and chiral stability of malathion in environmental samples. J Agric Food Chem. 2011;60:372-9.

8. Hegeman WJM, Laane RWPM. Enantiomeric enrichment of chiral pesticides in the environment. Rev Environ Contam Toxicol. 2002;173:85-116

9. Ahrens WH. Herbicide handbook. Champaign: Weed Science Society of America; 1994.

10. Geoffroy L, Teisseire H, Couderchet M, Vernet G. Effect of oxyfluorfen and diuron alone and in mixture on antioxidative enzymes of Scenedesmus obliquus. Pestic Biochem Physiol. 2002;72:178-85.

11. Jinno $H$, Hatakeyama N, Hanioka N, Yoda R, Nishimura T, Ando M. Cytotoxic and porphyrinogenic effects of diphenyl ethers in cultured rat hepatocytes: chlornitrofen (CNP), CNP-amino, chlomethoxyfen and bifenox. Food Chem Toxicol. 1999;37:69-74.

12. Laganà A, Fago G, Fasciani L, Marino A, Mosso M. Determination of diphenyl-ether herbicides and metabolites in natural waters using high-performance liquid chromatography with diode array tandem mass spectrometric detection. Anal Chim Acta. 2000;414:79-94.

13. Sheu HL, Sung YH, Melwanki MB, Huang SD. Determination of diphenylether herbicides in water samples by solid-phase microextraction coupled to liquid chromatography. J Sep Sci. 2006;29:2647-52.

14. Sondhia S. Persistence of oxyfluorfen in soil and detection of its residues in rice crop. Toxicol Environ Chem. 2009:91:425-33.

15. Diao JL, Xu P, Wang P, Lu DH, Lu YL, Zhou ZQ. Enantioselective degradation in sediment and aquatic toxicity to daphnia magna of the herbicide lactofen enantiomers. J Agric Food Chem. 2010;58:2439-45.

16. Diao JL, Lv CG, Wang XQ, Dang ZH, Zhu WT, Zhou ZQ. Influence of soil properties on the enantioselective degradation of the herbicide lactofen in soils. J Agric Food Chem. 2009;57:5865-71.

17. Liang B, Zhao YK, Lu P, Li SP, Huang X. Biotransformation of the diphenyl ether herbicide lactofen and purification of a lactofen esterase from Brevundimonas sp. LY-2. J Agric Food Chem. 2010;58:9711-5.

18. Fan XJ, Liu XL, Huang R, Liu YH. Identification and characterization of a novel thermostable pyrethroid-hydrolyzing enzyme isolated through metagenomic approach. Microb Cell Fact. 2002;11:33.
19. Iniesta AA, McGrath PT, Reisenauer A, McAdams HH, Shapiro LA. Phospho-signaling pathway controls the localization and activity of a protease complex critical for bacterial cell cycle progression. Proc Natl Acad Sci. 2006;103:10935-40.

20. Feller G, Thiry M, Gerday C. Nucleotide sequence of the lipase Gene lip3 from the antarctic psychotroph Moraxella TA144. Biochim Biophys Acta. 1991;1088:323-4

21. Arpigny JL, Feller G, Gerday C. Cloning, sequence and structural features of a lipase from the antarctic facultative psychrophile Psychrobacter immobilis B10. Biochim Biophys Acta. 1993;1171:331-3.

22. Ollis DL, Cheah E, Cygler M, Dijkstra B, Frolow F. The $\alpha / \beta$ hydrolase fold. Protein Eng. 1992;5:197-211.

23. Bornscheuer UT. Microbial carboxyl esterases: classification, properties and application in biocatalysis. FEMS Microbiol Rev. 2002;26:73-81.

24. Arpigny JL, Jaeger KE. Bacterial lipolytic enzymes: classification and properties. Biochem J. 1999:343:177-83.

25. Cheng C, Huang L, Ma R, Zhou ZQ, Diao JL. Enantioselective toxicity of lactofen and its metabolites in Scenedesmus obliquus. Algal Res. 2015; 10:72-9.

26. Wang F, Liu DH, Qu H, Chen L, Zhou ZQ, Wang P. A full evaluation for the enantiomeric impacts of lactofen and its metabolites on aquatic macrophyte Lemna minor. Water Res. 2016;15:55-63.

27. Sambrook J, Russell DW. Molecular cloning: a laboratory manual. 3rd ed. New York: Cold Spring Harbor; 2001.

28. Thompson JD, Higgins DG, Gibson TJ. CLUSTL W: improving the sensitivity of progressive multiple sequence alignment through sequence weighting, position-specific gap penalties and weight matrix choice. Nucleic Acids Res. 1994;22:4673-80.

29. Tamura K, Stecher G, Peterson D, Filipski A, Kumar S. MEGA6: molecular evolutionary genetics analysis version 6.0. Mol Biol Evol. 2013;30:2725-9.

30. Gao RJ, Feng Y, Ishikawa K, Ishida H, Ando S, Kosugib Y, Cao SG. Cloning, purification and properties of a hyperthermophilic esterase from archaeon Aeropyrum pernix K1. J Mol Catal B Enzym. 2003;24-25:1-8.

\section{Submit your next manuscript to BioMed Central and we will help you at every step:}

- We accept pre-submission inquiries

- Our selector tool helps you to find the most relevant journal

- We provide round the clock customer support

- Convenient online submission

- Thorough peer review

- Inclusion in PubMed and all major indexing services

- Maximum visibility for your research

Submit your manuscript at www.biomedcentral com/submit
O Biomed Central 